\title{
PERLINDUNGAN HUKUM TERHADAP NARAPIDANA LGBT DI LEMBAGA PEMASYARAKATAN MENURUT KONSEPSI HAK ASASI MANUSIA
}

\author{
Dianita Halim ${ }^{1}$, Tundjung Herning Sitabuana ${ }^{2}$ \\ ${ }^{1}$ Fakultas Hukum, Universitas Tarumanagara Jakarta \\ Email: dianita.207211007@stu.untar.ac.id \\ ${ }^{2}$ Dosen Magister Fakultas Hukum, Universitas Tarumanagara Jakarta \\ Email: tundjung@fh.untar.ac.id
}

\begin{abstract}
The debate about the pros and cons of supporting, protecting, and recognizing LGBT rights has existed since the early 19th century. In 2011, the United Nations declared a human rights resolution dedicated to sexual orientation and gender identity. The United Nations statement reaps many pros and cons from the countries that are members of it. Indonesia is one of those who disagree with this. In everyday life, LGBT people in Indonesia often face discrimination, harassment, and sexual violence even though law in Indonesia does not criminalize LGBT. The lives of LGBT who hold prisoner status are made more difficult because they often face discrimination, harassment, and sexual violence, both from other inmates and prison officials, but there is no positive law that supports the protection of LGBT. Therefore, this study aims to understand the form of legal protection for LGBT prisoners. The research method used is normative juridical research with a conceptual approach. The characteristic of human rights is universal and automatically attached to an individual because the individual is a human being. Human rights create an obligation for other individuals not to violate the rights of others and the obligation of the government to protect these rights. Indonesia is a rule of law. Through the concept of human rights and the rule of law, LGBT prisoners actually still have to be given legal protection against acts of discrimination committed by heterosexual prisoners and the need for law enforcement for acts of sexual violence. The government can actually apply several United Nations principles in the "Born Free and Equal" campaign to provide legal protection for LGBT prisoners who experienced discrimination, harassment, and sexual violence.
\end{abstract}

Keywords: Human Rights; Legal Protection; LGBT

\begin{abstract}
ABSTRAK
Naskah Perdebatan mengenai pro dan kontra dalam mendukung, melindungi, dan mengakui hak LGBT sudah ada sejak awal ke-19. Pada 2011, PBB menyatakan resolusi hak asasi manusia yang didedikasikan untuk orientasi seksual dan identitas gender. Pernyataan PBB menuai banyak pro dan kontra dari negara-negara yang tergabung di dalamnya. Indonesia adalah salah satu yang tidak sependapat dengan hal tersebut. Dalam kehidupan sehari-hari, kaum LGBT di Indonesia kerap mendapat diskriminasi, pelecehan, dan kekerasan seksual meski hukum di Indonesia tidak mengkriminalisasi LGBT. Kehidupan kaum LGBT yang menyandang status narapidana menjadi lebih berat karena sering mendapatkan diskriminasi, pelecehan, dan kekerasan seksual, baik dari narapidana lain maupun petugas lembaga pemasyarakatan, tetapi tidak ada hukum positif yang mendukung perlindungan kaum LGBT. Oleh karena itu, penelitian ini ditujukan untuk memahami bentuk perlindungan hukum bagi narapidana kaum LGBT. Metode penelitian yang digunakan adalah penelitian yuridis normatif dengan pendekatan konseptual. Hak asasi manusia adalah hak yang bersifat universal dan melekat secara otomatis kepada seseorang individu karena individu tersebut adalah manusia. Hak asasi manusia menimbulkan kewajiban bagi individu lain untuk tidak melanggar hak orang lain dan kewajiban pemerintah serta negara untuk melindungi hak-hak tersebut. Indonesia merupakan negara hukum. Melalui konsep hak asasi manusia dan negara hukum, maka narapidana kaum LGBT sebenarnya tetap harus diberi perlindungan hukum terhadap tindakan diskriminasi yang dilakukan oleh narapidana heteroseksual dan perlunya penegakan hukum atas tindak kekerasan seksual. Pemerintah sebenarnya dapat menerapkan beberapa prinsip PBB dalam kampanye "Born Free and Equal" untuk melakukan perlindungan hukum bagi narapidana kaum LGBT yang mengalami diskriminasi, pelecehan, dan kekerasan seksual.
\end{abstract}

Kata Kunci: Hak Asasi Manusia; Perlindungan Hukum; LGBT

\section{PENDAHULUAN}

Latar Belakang 
Persoalan mengenai LGBT (Lesbian, Gay, Bisex, Transgender) merupakan sebuah polemik yang sudah ada sejak lama dan mulai menjadi perdebatan sejak awal abad ke-19. Pada mulanya, banyak psikiater di Amerika yang menganggap bahwa LGBT adalah salah satu bentuk dari kelainan genetik, mental disorder, gangguan kepribadian sosiopat, dan kerap dikaitkan dengan gangguan-gangguan kesehatan yang lain. Hingga pada 1951, muncul seorang penulis dengan latar belakang sosiologi dan kriminologi, Donald Webster Cory, yang beranggapan bahwa LGBT merupakan sebuah perilaku normal dari suatu kelompok minoritas yang sah. Hal ini menyulut pergerakan untuk menghilangkan diskriminasi terhadap komunitas LGBT (Santoso, 2016).

Dukungan dan pengakuan terhadap kaum LGBT terus berkembang dan banyak diupayakan oleh berbagai pihak. Pada Juni 2011, salah satu Dewan PBB yang berasal dari Afrika Selatan menyatakan sebuah resolusi mengenai hak asasi manusia. Resolusi hak manusia tersebut ditujukan dan didedikasikan khusus untuk orientasi seksual dan identitas gender. Kemunculan resolusi tersebut menimbulkan banyak perdebatan dan tidak disetujui oleh beberapa negara Islam yang tergabung dalam PBB. Akan tetapi, Dewan Hak Asasi Manusia PBB yang telah mengakui LGBT meminta Komisaris Tinggi PBB, Navi Pillay, untuk memperjelas mekanisme perlindungan terhadap kasus kekerasan dan diskriminasi kaum LGBT. Pada 2015, Navi Pillay mengadakan kampanye "Born Free and Equal" secara global dan kampanye ini sejalan dengan keputusan Dewan Hak Asasi Manusia PBB untuk mengakui serta menegakkan perlindungan bagi kaum LGBT (Ammah dan Marwanto, 2019).

Akan tetapi, pengakuan PBB terhadap kaum LGBT tentu tidak membuat negara-negara yang tergabung dalam PBB turut mengakui dan mendukung kaum LGBT. Indonesia merupakan salah satu negara yang tidak mendukung dan mengakui kaum LGBT. Hukum positif yang ada di Indonesia dalam arti luas pun tidak memberi dukungan bagi komunitas LGBT meski tidak menggolongkan LGBT sebagai tindak pidana. Pada kenyataannya, seperti yang dilansir pada topikmalaysia.com, tertulis bahwa Indonesia merupakan negara ke-5 dengan jumlah populasi LGBT terbanyak di dunia. Penelitian independen dan survey CIA menyatakan bahwa dari keseluruhan penduduk Indonesia, 3\% diantaranya adalah kaum LGBT. Di Indonesia keberadaan kaum LGBT tidak mendapat legitimasi sehingga membawa polemik dalam realitas bermasyarakat, terlebih karena tingginya angka populasi kaum LGBT di Indonesia. Bahkan di Indonesia masih terdapat beberapa Peraturan Daerah yang melarang LGBT dan mengelompokkan LGBT sebagai salah satu tindak pidana karena dianggap tidak bermoral. Hal ini terdapat pada Perda Provinsi Sumatera Selatan Nomor 13 Tahun 2002 (Sofyarto, 2018).

Menurut Sutoyo dan Anwar (2019), dalam kehidupan bermasyarakat sehari-hari, kaum LGBT di Indonesia sudah kerap kali mendapatkan diskriminasi, pelecehan, dan kekerasan seksual. Hal ini terjadi secara lebih mengenaskan pada kaum LGBT yang menjadi narapidana dan tinggal di Lembaga Pemasyarakatan. Dalam Undang-Undang No. 12 Tahun 1995 tentang Pemasyarakatan memang dijelaskan bahwa terdapat beberapa hak narapidana yang dihilangkan, tetapi hak yang dihilangkan hanya hak kemerdekaannya saja. Tujuan pemasyarakatan pun bukan untuk memberikan siksaan secara mental dan fisik, melainkan untuk memberikan binaan kepada warga binaan agar dapat kembali ke kehidupan bermasyarakat. Lembaga Pemasyarakatan di Indonesia hanya terbagi menjadi Lapas Pembinaan Khusus Anak, Lapas Perempuan, dan Lapas Pria. Hal ini menyebabkan kaum LGBT akan ditempatkan di Lembaga Pemasyarakatan sesuai dengan statusnya yang diakui oleh negara. Dilansir di sebuah video wawancara detik.com dengan mantan narapidana Lapas di Jawa Barat, dijelaskan bahwa narapidana kaum LGBT di Lembaga Pemasyarakatan kerap dijadikan pemuasan kebutuhan biologis dari narapidana lain. Selain itu, hasil wawancara Sutoyo dan Anwar dengan petugas Lembaga Pemasyarakatan serta narapidana transgender di Lapas Kelas IIA Sumbawa Besar memperlihatkan bahwa banyak narapidana pria dan petugas Lembaga Pemasyarakatan yang acuh tak acuh dan secara implisit melakukan diskriminasi terhadap narapidana transgender. Dalam wawancara Sutoyo dan Anwar di Lapas 
Kelas IIA Sumbawa Besar juga terdapat pengakuan seorang narapidana transgender yang kerap dipaksa untuk memenuhi kebutuhan biologis narapidana lain. Penempatan narapidana transgender (transpuan) di Lembaga Pemasyarakatan pria juga dapat memberi tekanan psikologis tersendiri bagi individu tersebut dan tak jarang juga terjadi kekerasan serta pelecehan seksual terhadap narapidana transgender. Detik.com juga pernah melansir kasus pelecehan dan penyimpangan seksual narapidana kaum LGBT yang dilakukan petugas pemasyarakatan di Lembaga Pemasyarakatan Kelas IIB Cianjur pada tahun 2019. Polemik mengenai perlindungan dan penempatan narapidana kaum LGBT juga terjadi pada dua selebgram Indonesia yang melakukan penyalahgunaan obat terlarang.

Pada salah satu tajuk berita di detik.com, dikatakan bahwa Kemenkum HAM memiliki wacana untuk memisahkan narapidana LGBT ke 'kamar isolasi' karena adanya anggapan bahwa perilaku gay dan lesbian dapat menular. Namun, berdasarakan wawancara detik.com dengan seorang mantan narapidana yang pernah melihat hubungan seksual sesama jenis di Lembaga Pemasyarakatan, dijelaskan bahwa hubungan seksual sesama jenis di Lembaga Pemasyarakatan biasanya dilakukan oleh seseorang heteroseksual yang hanya sekedar ingin menyalurkan kebutuhan biologisnya. Tak jarang, bahwa narapidana kaum LGBT yang sesungguhnya lah yang mendapat paksaan dan kekerasan seksual. Dalam ilmu SOGIESC (Sexual Orientation, Gender Identity \& Expression, and Sex Characteristic), orientasi seksual tidak hanya berbicara ketertarikan antar individu secara erotis, tetapi juga meliputi ketertarikan yang melibatkan rasa emosi dan romantis. Jika melihat pemahaman tersebut, terlihat bahwa tidak semua narapidana yang melakukan hubungan sesama jenis termasuk kaum LGBT. Akan tetapi, pemerintah Indonesia pun telah secara tidak langsung melakukan diskriminasi pada narapidana kaum LGBT. Banyak penelitian-penelitian mengenai penempatan narapidana transgender dan analisis faktor pendorong perilaku homoseksual di Lembaga Pemasyarakatan telah dilakukan. Berbeda dengan penelitian yang telah ada sebelumnya, penelitian ini akan berfokus pada perlindungan hukum terhadap narapidana kaum LGBT menurut konsepsi hak asasi manusia. Oleh karena itu, melalui penelitian ini diharapkan muncul sebuah pemahaman mengenai bentuk perlindungan hukum bagi narapidana kaum LGBT yang mengalami perlakuan diskriminasi, pelecehan, dan kekerasan seksual, baik dari petugas Lembaga Pemasyarakatan atau narapidana lain, berdasarkan konsepsi hak asasi manusia.

\section{Rumusan Masalah}

Dengan diangkatnya topik mengenai perlindungan hak asasi manusia terhadap narapidana LGBT dan berdasarkan penjabaran latar belakang penelitian di atas, maka masalah yang teridentifikasi adalah sebagai berikut: Bagaimana bentuk perlindungan hukum terhadap narapidana LGBT yang mengalami diskriminasi, pelecehan, dan kekerasan seksual menurut konsepsi hak asasi manusia?

\section{METODE PENELITIAN}

Metode penelitian yang digunakan dalam penelitian ini adalah yuridis normatif dengan pendekatan konseptual. Menurut Marzuki (2021), pendekatan konseptual dalam penelitian hukum digunakan ketika sebuah analisis dalam penelitian tidak dimulai dan tidak didasarkan dari aturan hukum yang sudah ada. Hal ini dikarenakan memang belum adanya aturan hukum untuk isu hukum yang dihadapi. Dalam pendekatan ini peneliti akan menggunakan makna yang bersifat umum untuk membangun sebuah konsep (bersifat universal) yang dapat digunakan sebagai argumentasi hukum. Melalui pemahaman mengenai pendekatan konseptual dari Marzuki, metode penelitian yuridis normatif dengan pendekatan konseptual dirasa sesuai untuk menelaah bentuk perlindungan hukum bagi narapidana kaum LGBT karena hukum positif di Indonesia hanya mengakui gender perempuan dan laki-laki, tidak ada pengaturan dan pengakuan mengenai LGBT di dalam hukum positif Indonesia. Bahan hukum yang akan digunakan dalam penelitian 
ini adalah bahan hukum sekunder, yaitu buku teks hukum, pendapat ahli, dan jurnal, baik yang bersifat nasional dan internasional. Dalam penelitian ini, bahan hukum sekunder yang digunakan adalah Deklarasi Universal Hak-Hak Asasi Manusia (UDHR atau Universal Declaration of Human Rights) dan booklet rekomendasi PBB kepada negara-negara mengenai poin-poin kewajiban dalam melindungi HAM kaum LGBT yang dibuat sesuai usulan Navi Pillay. Bahan hukum primer berupa perundang-undangan juga akan digunakan di penelitian ini guna mendukung bahan hukum sekunder. Beberapa perundang-undangan tersebut adalah Peraturan Pemerintah No. 58 Tahun 1999, Undang Undang No. 12 Tahun 1995 tentang Pemasyarakatan, dan Undang Undang No. 39 Tahun 1999 tentang HAM.

\section{HASIL DAN PEMBAHASAN}

Perlindungan hukum, pengakuan, dan penegakan hak asasi manusia bagi kaum LGBT di Indonesia memang tidak terdapat secara eksplisit di seluruh hukum positif Indonesia. Akan tetapi, hal ini tidak dapat dijadikan alasan untuk tidak melakukan perlindungan hukum dan pemenuhan hak bagi kaum LGBT di Indonesia. Terlebih lagi dengan adanya data dari survey CIA yang menyatakan bahwa 3\% dari populasi warga Indonesia memiliki kelainan orientasi seksual (LGBT). Hak Asasi Manusia dalam Undang Undang Republik Indonesia Nomor 39 Tahun 1999 dideskripsikan sebagai seperangkat hak yang melekat sejak manusia lahir dan hak tersebut bersifat mutlak serta tidak dapat dikurangi dalam keadaan apapun dan oleh siapa pun. Hak-hak tersebut wajib dihormati, dijunjung tinggi dan dilindungi oleh semua pihak (negara, pemerintah, hukum, dan setiap individu lain) demi kehormatan serta perlindungan harkat dan martabat manusia. Sedangkan menurut Gibney (3003, hlm. 5), salah satu instrumen atau alat yang dapat digunakan untuk memperkuat dan melindungi seseorang adalah HAM. Dengan adanya HAM maka muncul standar-standar minimum mengenai bagaimana seseorang harus diperlakukan, apa yang seseorang berhak terima dari individu lain, dan apa saja hal yang dapat dilakukan oleh tiap individu dalam kehidupan.

Berdasarkan sejarah HAM, HAM yang berlaku saat ini merupakan hasil perkembangan pemikiran sejak Perang Dunia II. Seiring berjalannya waktu, dokumen-dokumen mengenai HAM semakin banyak bermunculan pada abad ke-20, salah satunya adalah Deklarasi Universal. Beberapa hal mengenai konsep HAM yang dapat disimpulkan oleh Nickel (1996) dari Deklarasi Universal antara lain:

1. Pada dasarnya, hak asasi manusia seseorang adalah hak.

2. HAM dimiliki seseorang semata-mata karena individu tersebut adalah manusia dan bersifat universal. Ras, agama, jenis kelamin, kewarganegaraan, dan kedudukan sosial tidak relevan untuk menentukan HAM seseorang. Sifat universal HAM menunjukkan bahwa HAM adalah hak internasional dan termasuk dalam objek perhatian dan aksi internasional yang dianggap sah.

3. HAM melekat pada diri seseorang secara otomatis. Dalam hal ini dapat disimpulkan bahwa pengakuan "kepemilikan" HAM dan penerapan HAM tidak bergantung dari suatu sistem hukum yang terdapat pada sebuah negara atau sebuah budaya adat. Pada praktiknya, hal ini memang belum efektif ketika belum dijalankan menurut hukum. Akan tetapi, hak ini tetap ada sebagai standar argumen dan kritik yang tidak bergantung pada penerapan hukum.

4. HAM dianggap sebagai norma-norma penting. Ada kalanya HAM tidak bersifat mutlak dan memiliki batasan tertentu. Akan tetapi, kedudukan HAM cukup kuat untuk dijadikan pertimbangan normatif ketika terjadi pertentangan dengan norma-norma nasional serta dapat digunakan untuk membenarkan aksi internasional yang dilakukan demi HAM. 
5. HAM memunculkan kewajiban bagi individu lain maupun pemerintah karena seseorang diwajibkan untuk tidak melanggar hak orang lain dan pemerintah wajib melindungi serta menegakkan hak-hak tersebut.

Melalui penjabaran konsepsi HAM dari Nickel, dapat disimpulkan bahwa HAM merupakan hak yang melekat secara otomatis kepada semua orang. Ras, agama, jenis kelamin, kewarganegaraan, serta kedudukan sosial tidak dapat dijadikan alasan dalam membatasi HAM seseorang. Dalam hal ini dapat dikatakan bahwa suatu negara, pemerintah, dan individu lain wajib melindungi, mengakui, dan menghormati HAM semua orang, baik masyarakat pada umumnya, kaum LGBT, bahkan hingga narapidana. Diskriminasi serta kurangnya perlindungan dan pemenuhan hak bagi kaum LGBT di Indonesia kebanyakan didasari pada stigma buruk yang ada dalam benak masyarakat sehingga menganggap LGBT sebagai sebuah mental disorder atau 'penyakit' yang dapat menular. Pada kenyataanya, American Psychiatric Association menjelaskan bahwa LGBT bukan sebuah mental disorder melainkan sebuah bentuk pengekspresian gender yang berbeda dari seseorang. Ketika berbicara mengenai pembatasan hak narapidana pun sebenarnya UU Pemasyarakatan pasal 5 menegaskan bahwa seorang narapidana hanya kehilangan hak kemerdekaannya saja. Sehingga seharusnya perlindungan hak asasi manusia terhadap narapidana kaum LGBT yang mengalami diskriminasi, pelecehan, dan kekerasan seksual tetap harus ditegakkan oleh pemerintah dan negara, terlebih karena Indonesia merupakan negara hukum.

Menurut Supandji dalam Handayani (2012), salah satu tujuan utama dari dibentuknya negara hukum adalah untuk melindungi HAM. Keadilan, penegakan hukum, dan HAM merupakan tiga istilah yang selalu melekat pada negara hukum (rechtsstaat). Jika suatu negara berpendapat bahwa dirinya adalah negara hukum, maka negara tersebut harus menjunjung keadilan karena keadilan merupakan hakikat dari hukum. Selain itu, dalam negara hukum, seluruh aspek tindakan pemerintah dan bermasyarakat harus didasarkan pada peraturan perundang-undangan atau berdasar legalitas. Pemerintah dan masyarakat tidak dapat melakukan tindakan tanpa dasar kewenangan.

Beberapa unsur pokok dalam suatu negara hukum menurut Fredrich Julius Stahl, yaitu: pengakuan dan perlindungan hak asasi manusia; negara berdasarkan teori trias politica; aspekaspek dan tindakan pemerintah didasarkan pada Undang-Undang; adanya peradilan administrasi negara yang menangani perbuatan melanggar hukum yang dilakukan oleh pemerintah (Yasir, 1998). Pada pasal 1 ayat (3) UUD Republik Indonesia Tahun 1945, dijabarkan secara jelas mengenai eksistensi Indonesia sebagai negara hukum. Seperti yang telah dijabarkan di atas, unsur utama dalam negara hukum adalah adanya jaminan terhadap HAM. Hal mengenai jaminan perlindungan HAM juga tertulis pada UUD Tahun 1945 bahwa setiap orang berhak hidup sejahtera secara lahir batin, bertempat tinggal, dan mendapat lingkungan hidup yang baik dan sehat. UU HAM pasal 3 juga mengatakan bahwa setiap orang berhak atas jaminan, pengakuan, perlakuan, serta perlindungan yang adil dan sama di hadapan hukum.

Menurut Purwanti (2016), terdapat tiga kewajiban dan tanggung jawab utama negara terhadap hak asasi manusia. Kewajiban dan tanggung jawab yang pertama adalah untuk menghormati hak-hak asasi manusia tiap warga negara, dimana negara dilarang untuk melakukan hal-hal yang dapat menghambat pemenuhan hak asasi manusia seseorang dan negara wajib untuk tidak ikut campur ketika seseorang melakukan hak-hak asasinya. Kewajiban kedua yang harus dilakukan oleh negara terhadap hak asasi manusia seseorang adalah untuk berperan aktif melindungi hak asasi manusia setiap warga negara dengan mengambil tindakan untuk mencegah terjadinya pelanggaran hak asasi manusia. Kewajiban dan tanggung jawab negara yang terakhir adalah untuk memenuhi hak-hak asasi manusia setiap orang dengan cara mengambil langkah hukum, administratif, maupun legislatif untuk merealisasikan hak-hak asasi manusia setiap orang secara penuh. 
Dalam praktik di lapangan, fakta dari media massa, dan menurut berbagai penelitian, tak jarang terdapat narapidana kaum LGBT di suatu lembaga pemasyarakatan. Narapidana kaum LGBT di lembaga pemasyarakatan kerap mengalami diskriminasi, pelecehan, dan kekerasan seksual di lembaga pemasyarakatan, baik dari narapidana lain maupun petugas pemasyarakatan. Tindakan diskriminasi, pelecehan, dan kekerasan seksual terhadap narapidana di lembaga pemasyarakatan tidak seharusnya disepelekan dan berakhir hanya diselesaikan dengan bentuk peleraian dari petugas pemasyarakatan atau mengisolasi narapidana kaum LGBT karena dianggap dapat "menularkan" penyimpangan seksualnya, terlebih jika melihat kembali kewajiban dan tanggung jawab negara terhadap hak asasi manusia seseorang (menghormati, melindungi, dan memenuhi). Dalam pasal 5 UDHR dijelaskan bahwa setiap orang tidak boleh diperlakukan secara kejam dan dihina. Menurut Nickel (1996), HAM seseorang memunculkan kewajiban bagi individu lain maupun pemerintah karena seseorang diwajibkan untuk tidak melanggar hak orang lain dan pemerintah wajib melindungi serta menegakkan hak-hak tersebut.

Arief (1998) menjelaskan bahwa ketika melakukan perlindungan hukum dalam hukum pidana terdapat peranan negara yang merupakan sebuah institusi, dimana kewenangan negara dapat mengaktifkan penegakan hukum dalam masyarakat sehingga seharusnya pemerintah Indonesia dapat melakukan penegakan hukum bagi narapidana kaum LGBT yang mengalami diskriminasi, pelecehan, dan kekerasan seksual. Dalam RUU KUHP pasal 421 dijelaskan bahwa setiap orang yang melakukan perbuatan cabul secara paksa di hadapan orang lain, baik dengan orang yang berbeda atau sesama jenis akan dipidana penjara paling lama satu tahun enam bulan. Selain itu, perbuatan cabul secara paksa juga dapat dikenakan pidana denda paling banyak Kategori III. Melalui pasal tersebut seharusnya seorang narapidana heteroseksual yang melakukan kekerasan seksual dan pelecehan terhadap narapidana LGBT di Lapas Jawa Barat dan Lapas Kelas IIA Sumbawa Besar tidak seharusnya hanya dianggap sebagai pemenuhan kebutuhan biologis satu sama lain melainkan harus dipandang sebagai tindak pidana dan pelanggaran HAM. Stigma yang buruk dalam benak masyarakat, petugas pemasyarakatan, serta beberapa orang dari pemerintahan malah mengarah pada diskriminasi dan pengucilan terhadap narapidana kaum LGBT karena adanya anggapan bahwa narapidana kaum LGBT yang "menularkan" homoseksualitas. Hal inilah yang menyebabkan narapidana kaum LGBT susah mendapat perlindungan hukum. Dalam Peraturan Pemerintah No. 58 Tahun 1999 Pasal 4 ayat (2) sebenarnya dijelaskan bahwa petugas pemasyarakatan bertugas untuk tetap melakukan perlindungan hak asasi manusia dan menjamin terpenuhinya hak narapidana sesuai UU Pemasyarakatan. Selain itu, dijelaskan juga bahwa petugas pemasyarakatan dalam menjalankan kewajibannya harus memegang asas praduga tak bersalah.

Perlindungan hukum terhadap narapidana kaum LGBT di lembaga pemasyarakatan juga dapat berprinsip pada rekomendasi PBB kepada negara-negara mengenai poin-poin kewajiban dalam melindungi HAM kaum LGBT, seperti:

1. Melindungi individu LGBT dari masyarakat atau seseorang yang homofobik dan perlindungan dari kekerasaan transfobik. PBB menyatakan hal ini karena dianggap selaras dengan pasal 3 UDHR yang menyatakan bahwa setiap orang berhak atas keselamatan sebagai individu, kehidupan, serta kebebasan.

2. Mencegah segala bentuk perlakuan yang kejam serta tidak manusiawi, tindakan penyiksaan, dan perlakuan yang merendahkan kaum LGBT. PBB menjelaskan bahwa pasal 5 dalam UDHR sendiri sebenarnya telah menjelaskan mengenai setiap orang tidak boleh diperlakukan secara kejam dan tidak manusiawi atau disiksa.

3. Mencabut Undang-Undang atau peraturan yang mengkriminalisasi homoseksualitas. Poin ketiga merupakan pengerucutan dari pasal 2 menyatakan bahwa setiap orang berhak atas hak-hak asasi manusia yang terdapat dalam UDHR tanpa pengecualian apapun, termasuk 
pengecualian terhadap jenis kelamin. Selain itu, poin dekriminalisasi homoseksual juga sejalan dengan pasal 9 UDHR (mengenai larangan untuk menangkap, menahan, dan membuang orang dengan sewenang-wenang) dan pasal 12 UDHR (mengenai orang lain tidak diperbolehkan mengganggu urusan pribadi, keluarga, rumah tangga, atau hubungan surat-menyurat seseorang dengan sewenang-wenang serta tidak diperkenankannya pelanggaran atas kehormatan nama baik seseorang).

4. Melarang adanya diskriminasi berdasarkan orientasi seksual dan identitas gender. Pada pasal 7 UDHR juga dijelaskan bahwa setiap orang sama di hadapan hukum dan berhak untuk mendapatkan perlindungan hukum yang sama.

5. Menghargai kebebasan bagi kaum LGBT untuk berkumpul, berserikat, dan berekspresi. PBB menjelaskan bahwa poin terakhir ini selaras dengan pasal 19 UDHR mengenai kebebasan berpendapat serta berekspresi dan sesuai dengan pasal 20 UDHR mengenai kebebasan berserikat dan berkumpul.

Pada tahun 2007, Komnas HAM sebenarnya telah menerbitkan Yogyakarta Principle atau Prinsip Yogyakarta yang menjelaskan mengenai prinsip pemberlakuan hukum HAM Internasional dalam kaitannya dengan orientasi seksual dan gender. Prinsip Yogyakarta sebenarnya ditujukan agar dapat membantu pemerintah menghapus stigma dan diskriminasi pada kaum LGBT di Indonesia.

Jika menelaah polemik perlindungan serta penempatan narapidana kaum LGBT di Lembaga Pemasyarakatan dan melihat rekomendasi PBB atas perlindungan hak asasi manusia kaum LGBT, beberapa bentuk perlindungan hak asasi manusia terhadap narapidana kaum LGBT di Lapas Jawa Barat, Lapas Kelas IIB Cianjur, dan Lapas Kelas IIA Sumbawa Besar adalah dengan tidak melakukan isolasi pada narapidana LGBT yang telah dipaksa melakukan pemuasan kebutuhan biologis narapidana lain maupun petugas pemasyarakatan meskipun telah diusulkan oleh Kemenkum HAM karena hal tersebut merupakan salah satu bentuk diskriminasi oleh pemerintah. Berdasarkan penjabaran mengenai pelanggaran negara terhadap hak asasi manusia seseorang menurut Purwanti (2016), hal ini termasuk ke dalam bentuk pelanggaran hak asasi manusia karena pembiaran (by omission), yaitu pelanggaran yang muncul karena negara tidak mengambil tindakan yang sesuai atau tindakan lebih lanjut dalam menjalankan kewajiban dan tanggung jawabnya terhadap hak asasi manusia. Pemerintah seharusnya menindaklanjuti narapidana dan petugas pemasyarakatan yang melakukan pelecehan karena menurut RUU KUHP pasal 421 dijelaskan bahwa setiap orang yang melakukan perbuatan cabul secara paksa di hadapan orang lain, baik dengan orang yang berbeda atau sesama jenis akan dipidana penjara paling lama 1 tahun 6 bulan atau pidana denda paling banyak Kategori III. Selain itu, dalam upaya perlindungan narapidana kaum LGBT dan mencegah terjadinya kekerasan seksual, pelecehan, dan diskriminasi terhadap narapidana transgender, seharusnya pemerintah dapat menjadikan putusan Pengadilan Negeri Jakarta Selatan Nomor 1230/Pdt.P/2019/PN JKT. SEL sebagai referensi. Melalui putusan tersebut, seseorang selebgram transgender yang melakukan penyalahgunaan obat terlarang ditempatkan di lapas perempuan karena telah mendapat legalitas negara mengenai gendernya. Selain itu, seperti yang dilansir indopolitika.com, di Indonesia terdapat beberapa rutan dan lapas yang memiliki sel khusus untuk kaum LGBT yang ditujukan untuk mencegah terjadinya diskriminasi pada narapidana kaum LGBT.

\section{KESIMPULAN DAN SARAN}

Berdasarkan hasil pembahasan di atas, maka dapat disimpulkan bahwa: Diskriminasi, pelecehan, dan kekerasan seksual yang dilakukan narapidana heteroseksual maupun petugas pemasyarakatan terhadap narapidana kaum LGBT dapat dikategorikan sebagai tindak pidana dan pelanggaran HAM dan petugas pemasyarakatan serta negara seharusnya bertugas untuk 
melindungi hak asasi manusia narapidana kaum LGBT. Perlindungan hukum terhadap narapidana kaum LGBT dapat berprinsip pada rekomendasi PBB mengenai kewajiban negara dalam perlindungan kaum LGBT.

Adapun saran untuk perlindungan hukum bagi narapidana kaum LGBT adalah adanya pemisahan lembaga pemasyarakatan bagi kaum transgender karena dalam UU Pemasyarakatan Pasal 12 pun sebenarnya dijelaskan bahwa pembinaan di lembaga pemasyarakatan dapat digolongkan berdasarkan kriteria lain sesuai dengan kebutuhan dan perkembangan pembinaan. Selain itu, dalam upaya melindungi narapidana kaum LGBT selain transgender seharusnya pemerintah mulai mengolah Prinsip Yogyakarta agar stigma buruk masyarakat Indonesia dan petugas pemasyarakatan terhadap kaum LGBT dapat berkurang sehingga berdampak juga pada berkurangnya diskriminasi pada kaum LGBT.

\section{Ucapan Terima Kasih (Acknowledgement)}

Ucapan terima kasih kepada pihak-pihak yang telah membantu dan membimbing penulisan penelitian ini serta kepada Lembaga Penelitian dan Pengabdian Kepada Masyarakat Universitas Tarumanagara karena telah merealisasikan SENAPENMAS 2021.

\section{REFERENSI}

Ammah, D. M., \& Marwanto. (2019). Perlindungan Internasional Terhadap Hak Asasi Manusia Orang-Orang LGBT dengan Bantuan PBB. Kertha Negara, 7(7), 1-16.

Arief, B. N. (1998). Kebijakan Hukum Pidana (Penal Policy), bahan Penataran Nasional Hukum Pidana dan Kriminologi. Fakultas Hukum Universitas Diponegoro, Semarang.

Booklet born free and equal. OHCHR. (n.d.). Retrieved September 25, 2021, from https://www.ohchr.org/en/issues/discrimination/pages/bornfreeequalbooklet.aspx.

Gibney, M. J. (2003). Introduction to Globalizing Rights. Oxford University Press.

Hadjon, P. M. (1987). Perlindungan Hukum Bagi Rakyat di Indonesia. PT Bina Ilmu, Surabaya.

Handayani, Y. (2012). Pemenuhan Hak Kesehatan Atas Narapidana Wanita di Lembaga Pemasyarakatan Wanita Kelas IIA Tangerang Periode Tahun 2011. Fakultas Hukum Universitas Indonesia, Depok.

Marzuki, P. M. (2021). Penelitian Hukum (Edisi Revisi). Prenadamedia Group, Jakarta.

Memahami istilah LGBT Lebih Dalam. DPPKBPMD Bantul. (2021, April 17). Retrieved September 25, 2021, from https://dppkbpmd.bantulkab.go.id/memahami-istilah-lgbt-lebihdalam/.

Nickel. J. W. (1996). Hak Asasi Manusia: Refleksi Filosofis atas Deklarasi Universal Hak Asasi Manusia. PT Gramedia Pustaka Utama, Jakarta.

Purwanti, M. (2016). Kewajiban dan Tanggung Jawab Negara dalam Pemenuhan Hak Asasi Manusia. Legal Smart Channel. Retrieved October 12, 2021, from https://lsc.bphn.go.id/artikel?id=365.

Santoso, M. B. (2016). LGBT dalam Perspektif Hak Asasi Manusia. Share: Social Work Journal, 6(2), 154-272.

Sofyarto, K. (2018). Abu-Abu Regulasi LGBT di Indonesia. Jurnal Selisik, 4(6), 84-94.

Sutoyo, A., \& Anwar, U. (2019). Perlakuan Terhadap Narapidana Berkarakter Transgender di Lembaga Pemasyarakatan Kelas IIA Sumbawa Besar. Journal of Correctional Issues, 2(1), $1-15$.

Yasir, A. Hukum Tata Negara Indonesia. (1998). Fakultas Hukum Universitas Lampung, Bandar Lampung. 